\title{
norden
}

\section{Wildlife and Infectious Animal Diseases}

The Proceedings of a Nordic -Baltic seminar on the role of the wildlife as reservoir and/or spread of infectious animal diseases in the coastal areas of countries bordering the Baltic Sea 2-3 October 2013, Gdansk, Poland
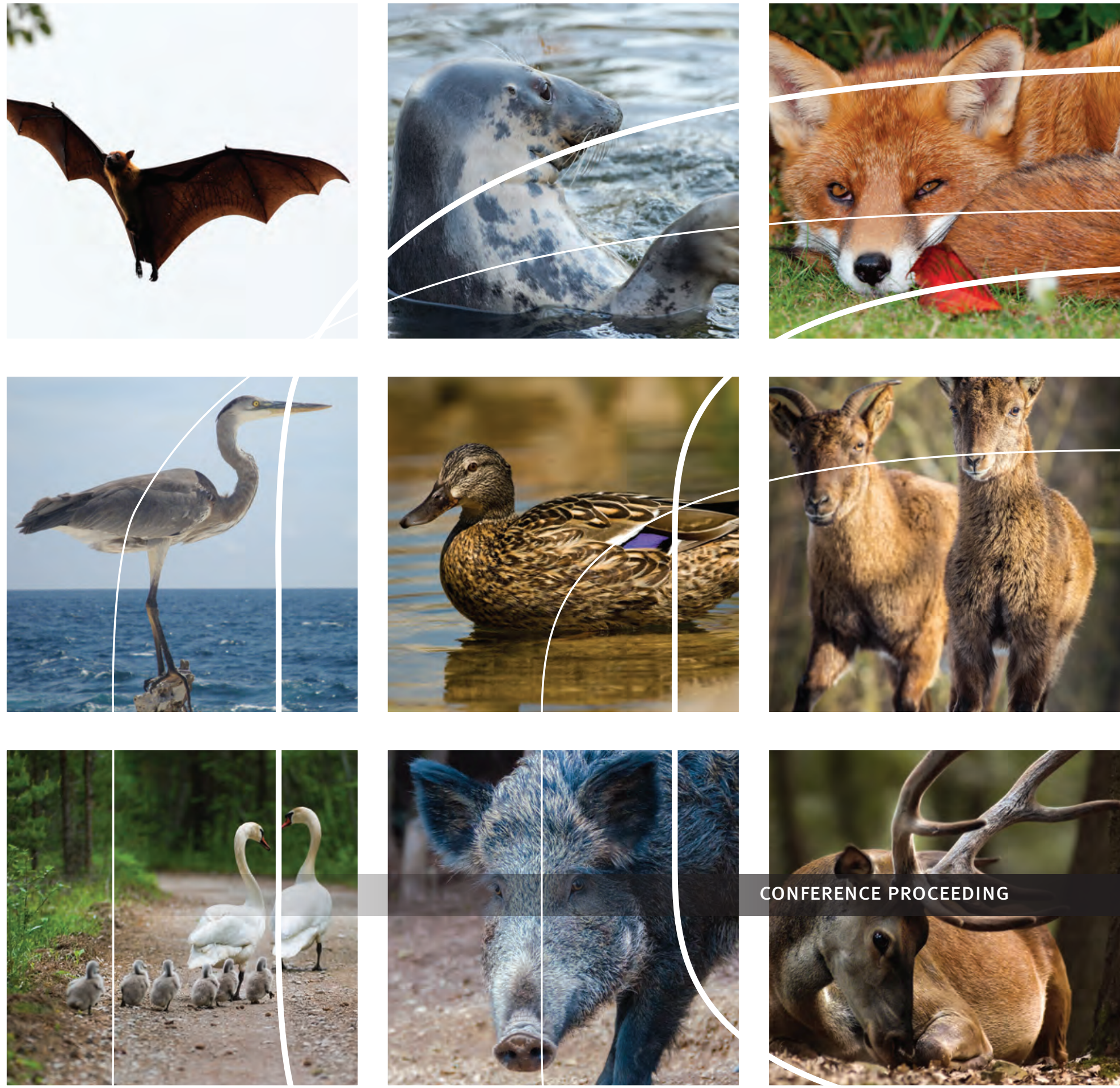

4 norden 



\section{Wildlife and Infectious Animal Diseases}

The Proceedings of a Nordic -Baltic seminar on the role of the wildlife as reservoir and/or spread of infectious animal diseases in the coastal areas of countries bordering the Baltic Sea 2-3 October 2013, Gdansk, Poland

Jørgen M. Westergaard

TemaNord 2014:508 
Wildlife and Infectious Animal Diseases

The Proceedings of a Nordic -Baltic seminar on the role of the wildlife as reservoir and/or spread of infectious animal diseases in the coastal areas of countries bordering the Baltic Sea 2-3 October 2013, Gdansk, Poland

Jørgen M. Westergaard

ISBN 978-92-893-2710-7

http://dx.doi.org/10.6027/TN2014-508

TemaNord 2014:508

ISSN 0908-6692

(C) Nordic Council of Ministers 2014

Layout: Hanne Lebech

Cover photo: ImageSelect; Jørgen M. Westergaard

This publication has been published with financial support by the Nordic Council of Ministers. However, the contents of this publication do not necessarily reflect the views, policies or recommendations of the Nordic Council of Ministers.

www.norden.org/en/publications

\section{Nordic co-operation}

Nordic co-operation is one of the world's most extensive forms of regional collaboration, involving Denmark, Finland, Iceland, Norway, Sweden, and the Faroe Islands, Greenland, and Åland.

Nordic co-operation has firm traditions in politics, the economy, and culture. It plays an important role in European and international collaboration, and aims at creating a strong Nordic community in a strong Europe.

Nordic co-operation seeks to safeguard Nordic and regional interests and principles in the global community. Common Nordic values help the region solidify its position as one of the world's most innovative and competitive.

\section{Nordic Council of Ministers}

Ved Stranden 18

DK-1061 Copenhagen K

Phone (+45) 33960200

www.norden.org 


\section{Content}

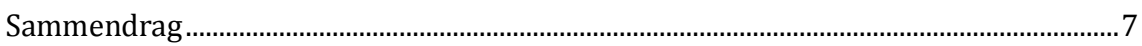

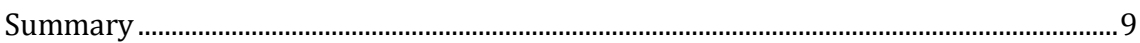

1. Opening session.................................................................................................. 11

2. Abstracts ........................................................................................................................... 13

2.1 Session I: Infectious diseases of wildlife and on-going research activities................................................................................................................... 13

2.1.1 Infectious diseases and the role of wildlife: emergence and detection of infection.............................................................................. 13

2.2 Session II: The bird and bat wildlife population: biodiversity, migrating birds and bats and reservoir for infectious diseases ................... 14

2.2.1 The avian wildlife population in the Baltic Sea Area ........................... 14

2.2.2 Potential of viral diseases in the bird population................................ 15

2.2.3 Experiences gained from avian influenza surveillance of the bird population in Poland ..................................................................... 16

2.2.4 Importance of the coastal area of Baltic Sea for bat migration......... 17

2.2.5 Observations from FVO audits of monitoring and eradication programmes for diseases affecting wildlife.......................................... 18

2.3 Sesion III: The mammal wildlife population: biodiversity and reservoir for infectious diseases

2.3.1 Report on the activities of the OIE Regional Representation in Moscow in 2013.

2.3.2 Mammalian wildlife of importance for the control of infectious diseases in countries surrounding the Baltic Sea

2.3.3 Epidemic surveillance and control of infectious animal diseases in the Leningrad and Kaliningrad Oblasts of the Russian Federation

2.3.4 Experiences from surveillance and monitoring programs for diseases in marine mammals................................................................. 22

2.3.5 The wild boar and classical swine fever in Latvia .............................. 23

2.3.6 The epidemiological situation of Rabies and implementation of disease eradication measures...

2.3.7 Rodent-Borne Pathogens Around The Baltic......................................... 25

2.4 Session IV: Wildlife diseases and contingency planning ................................. 26

2.4.1 How will the climatic change affect the ecosystems of the Baltic Sea coastal areas?

2.4.2 Contingency planning: How to respond to the wildlife/production animals' interface?

3. Observations, Conclusions and Recommendations................................................... 29

3.1 Recommendations.......................................................................................... 30

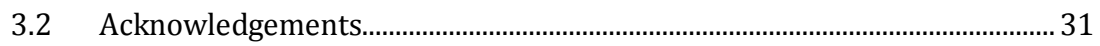

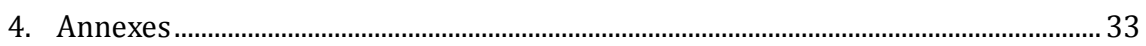

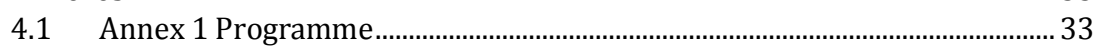

4.2 Annex 2. The Organizing Committee ............................................................... 34

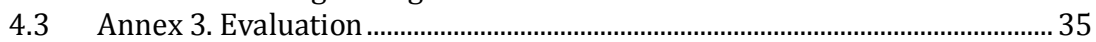

4.3.1 Organization chart ................................................................................. 37

4.4 Annex 4. List of participants........................................................................ 38 



\section{Sammendrag}

Det Nordisk- Baltiske seminar omhandlende betydningen af dyreliv (den vilde fauna) som reservoir og/eller for spredning af smitsomme dyresygdomme i kystområder i de lande, der grænser op til Østersøen, blev afholdt i Gdansk, Polen fra den 2-3 oktober 2013.

Formålet med seminaret omfattede:

- At gennemgå dyrelivsbestanden som reservoir for smitsomme sygdomme, herunder fugleinfluenza, sygdomme hos vildsvin, hundegalskab og vektorbårne sygdomme.

- At skitsere den potentielle risiko for spredning af smitsomme sygdomme via dyrelivet in Østersøens kystområder.

- At gennemgå risikobaseret overvågning for smitsomme sygdomme, som forekommer eller måtte forekomme i terrestriske dyr i kystområdet i lyset af klimaændringer.

- At undersøge muligheden for at etablere sygdomsovervågningen mere effektivt og opnå besparelser i forhold til laboratoriemæssige undersøgelser.

Endvidere havde seminaret fokus på hvorledes man kan reagere overfor kontaktfladerne imellem dyreliv og produktions dyr.

På den første dag af seminaret blev det belyst, hvorledes dyrelivet har stor økonomisk, økologisk, social og kulturel værdi for Østersøens kystområder, og hvorledes det fremmer rekreation og turisme. Desuden, blev der givet oplysninger om: OIEs ${ }^{1}$ arbejdsgruppe som behandler sygdomme i dyr i naturen; fugle populationen i Østersøområdet; smitsomme virus sygdomme i vilde fugle; sygdomsovervågningsprogrammer; migration af flagermus og observationer fra EU's inspektionsrejser vedrørende overvågning af dyrelivets sygdomme.

På seminarets 2. dag var der fokus på det terrestriske dyreliv med hensyn til biodiversitet og reservoir for smitsomme sygdomme, sygdomsovervågning, kontaktfladerne imellem dyrelivet og mennesker med hensyn til visse smitsomme sygdomme og beredskabsplanlægning vedrørende veterinærmyndigheders foranstaltninger til håndtering af kontakten imellem husdyr og dyrelivet i naturen. 
Seminaret havde mere end 90 deltagere som kom fra de ni lande der grænser op til Østersøen - Danmark, Sverige, Finland, Rusland, Estland, Letland, Litauen, Polen og Tyskland - og fra Island og Norge.

Udbyttet af seminaret omfattede:

- Konstruktive dialoger.

- Tæt samarbejde imellem videnskabsfolk, der arbejder med dyr i naturen, repræsentanter fra veterinære administrationer, der arbejder på central og lokal niveau, husdyr ejere, myndigheder og managers involveret $\mathrm{i}$ beskyttelse af dyr i naturen og i beskyttelse af dyrs og menneskers sundhed.

- Godt samarbejde imellem deltagere fra lande med en fælles landegrænse.

Alle indlæg på seminaret, som blev givet af foredragsholdere bosat i lande omkring Østersøen og foredragsholdere, der repræsenterede henholdsvis EU og OIE, gav et enestående grundlag for værdifuld udveksling af synspunkter imellem foredragsholderne, eksperter og seminarets $\emptyset$ vrige deltagere.

I lyset af drøftelserne og udveksling af synspunkter under seminaret kunne alle deltagerne i seminaret i den afsluttende samling vedtage 4 anbefalinger. Disse anbefalinger har fokus på:

- Sygdomsovervågning i grænseområderne imellem forskellige lande.

- Beredskabsøvelser, som retter sig mod truslen fra sygdomme i dyrelivet i naturen.

- Målrettet aktiv sygdomsovervågning med hensyn til fugleinfluenza i fugle i naturen.

- Planlægning, gennemførsel og evaluering af overvågningsprogrammer for sygdomme i dyr i naturen.

Den fulde ordlyd af anbefalingerne er givet i afsnittet, der omtaler observationer, konklusioner og anbefalinger. 


\section{Summary}

The Nordic -Baltic seminar on the role of wildlife as reservoir and/or spread of infectious animal diseases in the coastal areas of countries bordering the Baltic Sea was held in Gdansk, Poland from 2-3 October 2013.

The objectives of the seminar included

- To review the wildlife populations as reservoirs for infectious diseases such as avian influenza, diseases of wild boar, rabies and vector borne diseases.

- To outline the potential risk of spreading infectious animal diseases by wildlife inhabiting the coastal areas of the Baltic Sea.

- To review risk based surveillance of infectious diseases occurring or potentially occurring in terrestrial animals in the coastal area in the light of climatic changes.

- To explore the possibility in making disease surveillance more efficient and obtain savings in relation to laboratory examinations.

Furthermore, the seminar had focus on how to respond to the wildlife/production animals' interface.

Day one of the seminar highlighted how the wildlife have high economic, ecological, social and cultural value for the coastal areas bordering the Baltic Sea and have it contributes to recreation and tourism. Furthermore information was provided on activities of OIEs working group on wildlife diseases, the Baltic Sea avian wildlife population, infectious viral diseases in bird populations, disease surveillance programmes, bat migration and observations from EU audits covering monitoring and surveillance of diseases affecting wildlife.

The second day had focus on the mammal wildlife population with regard to biodiversity and reservoir for infectious diseases, disease surveillance and monitoring programmes, the wildlife/human interface concerning certain infectious diseases and contingency planning with regard to the response of veterinary services to the wildlife/production animals' interface.

The seminar had more than 90 participants coming from the nine countries - Denmark, Sweden, Finland, Russia, Estonia, Latvia, Lithuania, Poland and Germany - bordering the Baltic Sea and from Iceland and Norway.

The seminar showed the importance of having:

- Constructive dialogues and close cooperation between wildlife scientists, veterinary administrations at central and local level, 
livestock owners, the public and managers involved in the protection of wildlife and in the protection of animal and human health.

- Good cross border cooperation between neighbouring countries.

The presentations made during the seminar by speakers coming from the countries bordering the Baltic Sea, the OIE and the EU provided an excellent basis for a valuable exchange of views between the experts and the participants of the seminar.

In the light of the discussions and exchange of views during the seminar the participants adopted during the final session 4 recommendations. The recommendations have focus on:

- Disease surveillance in border areas between different countries.

- Simulation exercises addressing the threat of wildlife diseases.

- Targeted active surveillance of avian influenza in wild birds.

- Planning, implementation and evaluation of wildlife disease surveillance programmes.

The full text of the recommendations is presented in the section observations, conclusions and recommendations. 


\section{Opening session}

The participants were at the opening session welcomed by Dr. Krysztof Jazdzewski, Deputy Chief Veterinary Officer of Poland and Dr. Audur Arnthorsdottir, Chairman of the Nordic-Baltic Veterinary Contingency Group. In his opening speech Dr. Jazdzewski emphasized the importance of cooperation between the veterinary administrations in the countries bordering the Baltic Sea with regard to disease surveillance and application of disease control measures. It was a pleasure for the veterinary administration that Poland had been chosen as host country for the seminar and his administration would be pleased to provide assistance also in the future for seminars, workshops and other activities organized by the Nordic-Baltic Veterinary Contingency Group.

The opening speech delivered by Dr. Audur Arnthorsdottir is presented below:

As chairman of the Nordic-Baltic Veterinary Contingency Group, I wish to welcome you to this seminar.

To start with I want to thank our Polish friends and colleagues very much for inviting us to have the seminar here and the invaluable support from both the local veterinary administration here in Gdansk and the headquarters in Warszawa in the preparations of the seminar. I hope that this is only the first step towards a closer cooperation of the countries in this region in the field of veterinary contingency planning.

Now I will say a few words about the background and the purpose of the group behind this arrangement. In 2006, the Nordic Council of Ministers adopted a strategy which included plans for a closer cooperation between the Nordic and Baltic countries in the field of veterinary contingency planning. The plan emphasized that exotic animal infectious disease, with zoonotic potential as well as emerging diseases, should be prioritized. Subsequently the Nordic-Baltic Veterinary Contingency Group was established. The group consists of members from the veterinary authorities of the Nordic and the Baltic countries. The main purpose of the group is to achieve a common understanding between key personnel in the veterinary administrations and scientific institutions, of the risks related to introduction of exotic infectious animal diseases. In addition the aim is to enhance awareness of epizootic diseases, to identify areas of improvement in veterinary contingency planning and build bridges between veterinary administrations of the Nordic and the Baltic countries. In order to reach its goal, the group has arranged a number of activities during the years. Those include international simulation exer- 
cises on epizootic diseases, seminars with invited speakers, expert meetings, training activities and observer activities on international exercises. The group members keep a close contact through e-mails and at least three meetings every year. Fortunately, the membership of the group has been quite stable, which contributes to a productive and efficient performance.

The current members of the Nordic Baltic Veterinary Contingency Group are: Sirpa Kiviruusu from Finland, Maarja Kristian from Estonia, Edvins Olsevskis from Latvia, Egidijus Pumputis from Lithuania, Hanne M. Hansen from Denmark, Elisabet Lindal from Sweden, Siri Løtvedt from Norway and Audur Lilja Arnthorsdottir from Iceland. The group's consultant and an invaluable support for the group from the very beginning is Dr. Jørgen Westergaard. He is also the main organizer and has led the preparations for this seminar.

The Nordic Council of Ministers has for years focused on strengthening the cooperation between the countries around the Baltic Sea and has in this context had a good collaboration with the European Commission through the EU Strategy for the Baltic-Sea Region. This seminar is partly funded through that Strategy.

At the seminar that is now about to start we will look into the impact of wildlife in the coastal areas of the Baltic Sea, on the spreading of infectious animal diseases and we will also discuss the disease surveillance among the wildlife population in the area. Our hope is that this will contribute to a closer cooperation between the countries regarding the surveillance of infectious animal diseases and make the surveillance more efficient and less expensive.

I sincerely hope you will enjoy the seminar and that you will leave with both new knowledge and not least new contacts in the neighbouring countries. 


\section{Abstracts}

\subsection{Session I: Infectious diseases of wildlife and on- going research activities}

\subsubsection{Infectious diseases and the role of wildlife: emergence and detection of infection}

Dolores Gavier-Widén, National Veterinary Institute (SVA), Uppsala, Sweden

Wild animals have high economic, social, ecological and cultural value and play fundamental roles in the maintenance of stable ecosystems. Wildlife contributes significantly to recreation and tourism. Wildlife trade and natural migration contribute to the worldwide spread of new pathogens. Wildlife mass mortality results in public concern. Infectious diseases may have a devastating impact on wildlife populations and threaten their conservation. Wild animals host many pathogens and may act as reservoirs, maintaining infections in the ecosystem, which makes control and eradication difficult and has important health and economic impact on humans and livestock. Therefore, the value of maintaining naturally diverse and healthy wildlife populations cannot be overestimated.

Emerging infectious diseases (EID) are infections characterized by changes in their epidemiological presentation: new pathogens or newly evolved strains of existing pathogens, spread to new geographic area or to new populations, increase in prevalence, detection of previously unrecognized pathogens and old infections reemerging as a result of antimicrobial resistance. EID in humans are dominated by zoonoses $(60 \%$ of EID events), $72 \%$ of these are caused by pathogens with a wildlife origin and this rate has increased significantly with time (controlling for reporting effort). Vector-borne diseases are frequent among EID events.

Wildlife disease surveillance is a very extensive field involving different diagnostic disciplines, epidemiology and communication activities. Networking across disciplines and national boundaries is of great benefit in surveillance programs. As a whole, more than 18,000 wild animals are investigated by general ("passive") surveillance and more than 50,000 by targeted ("active") surveillance annually in Europe. New diagnostic tools for wildlife are being developed, for example within the WildTech EU project (http://www.wildtechproject.com/wildtech/). The OIE has established an ad hoc group to draft guidelines on "Principles 
and methods for the validation of diagnostic tests for infectious diseases applicable to wildlife."

Good knowledge and rapid identification of infections occurring in wildlife are essential for the design and implementation of preventing, control and mitigating measures to protect the health of humans and animals.

\subsection{Session II: The bird and bat wildlife population: biodiversity, migrating birds and bats and reservoir for infectious diseases}

\subsubsection{The avian wildlife population in the Baltic Sea Area}

Antra Stīpniece, Institute of Biology, University of Latvia, Salaspils

Human population (ca 154 millions) shares the Baltic Sea area with some 1,000-1,500 millions breeding pairs of 200-250 bird species. Some bird species are sedentary (e.g. Galliformes, most woodpeckers, and some tits). Long distance migrants leave and return comparatively predictably (migration triggered by changes in day length) and can meet disease sources in Africa and India. Short distance migrants' leave is triggered by weather and food conditions and most of them do not leave Europe. Species populations are spatially organized in flyways. Probability to meet individuals from other flyways and exchange diseases increases during harsh winters due to cold weather movements. Sea duck species breeding in Russia north use the Baltic Sea as wintering site. Breeding and wintering populations and bird movements are monitored by different methods (e.g. regular counts, ringing, and satellite telemetry). Recent studies reveal changes in bird distribution and numbers, probably due to climate and habitat change. 


\subsubsection{Potential of viral diseases in the bird population}

Timm C. Harder, Institute for Diagnostic Virology, Friedrich-LoefflerInstitut, Insel Riems, Germany, Ute Ziegler, Institute for Novel and Emerging Diseases, Friedrich-Loeffler-Institut, Insel Riems, Germany and Christian Grund Institute for Diagnostic Virology, Friedrich-Loeffler-Institut, Insel Riems, Germany

Wild bird populations constitute a highly diverse, sometimes extremely mobile and, with respect to population densities, abruptly fluctuating reservoir for various virus species. The presence and perpetuation of these agents in wild birds is driven by an intricate factorial network including species-specific (genetic) background, individual constitution, population dynamics, geographical location, season, to name a few. Anthropogenic factors such as habitat competition, environmental pollution and the revolutionary agronomical changes towards large scale industrial poultry rearing systems play an important role as well. Accidental spill-over infections may eventually lead to the emergence of avian-origin pathogens with zoonotic potential.

The role of aquatic wild bird populations as reservoirs of influenza $\mathrm{A}$ viruses (IAV) has been unraveled some 50 years ago. The full variety of at least 16 hemagglutinin and 9 neuraminidase subtypes and countless variants thereof, including some with zoonotic potential, is maintained in the aquatic wild bird metapopulation. Some peri-domestic passerine species may act as bridging hosts between the habitats of aquatic wild birds and poultry premises. Along with IAV aquatic wild birds also maintain infections with avian paramyxoviruses (APMV) of which, so far, 12 serotypes have been distinguished with APMV-1 being most relevant for poultry. Whereas class I APMV-1 is regularly detected in wild aquatic birds without any clinical signs, class II APMV- 1 are perpetuated in poultry and may cause highly lethal Newcastle disease. Further viruses such as duck adenovirus-1, which causes egg drop syndrome in layer chickens and a plethora of coronaviruses also have reservoirs in aquatic wild birds.

West Nile virus (WNV) is a mosquito-borne flavivirus, is transmitted in an avian cycle by ornithophilic mosquitoes and mainly passerines serve as primary vertebrate hosts of the virus. Recent WNV outbreaks or virus activity were observed in several European countries. Migratory birds can act as long distance carriers for this zoonotic pathogen and detection of WNV antibodies in resident bird populations is indicative for local virus circulation. Virological and serological surveillance in over 4,000 migratory and resident birds captured in Germany during 2007-2013 revealed absence of WNV-reactive antibodies in resident birds and of WNV-specific RNA in all investigated bird samples, indicating that there is currently no evidence for WNV circulation in Germany. In contrast to WNV, the related Usutu virus 
(USUV) has recently caused epizootics among wild and captive birds in southwest Germany.

Given the volatility of many viral pathogens in wild bird populations, continuing close-meshed surveillance is the only approach to maintain an idea, however fragmentary, of the fluxes and dynamics of these pathogens in avian populations including those of the Baltic region. Such knowledge forms the basis of any risk assessments regarding spill-over infections at the interfaces of wild birds, poultry and man.

\subsubsection{Experiences gained from avian influenza surveillance of the bird population in Poland}

Krzysztof Smietanka, Zenon Minta, National Veterinary Research Institute, Department of Poultry Diseases, Puławy, Poland

In Poland, the national surveillance for avian influenza in wild birds has been carried out according to Council Directive 2005/94/EC and guidelines laid down in specific Commission Decisions with the following goals: i) "baseline" surveillance of different species of birds as part of monitoring of low pathogenic avian influenza (LPAI) viruses (up to 2011) and ii) early detection of H5N1 highly pathogenic avian influenza (HPAI) virus. Moreover, since 2007, the program has been extended by testing samples in the framework of research projects and the active surveillance component, although limited, is still ongoing.

Approximately 8,000 birds were tested for the purpose of the national survey in the past 5 years.

The following conclusions can be drawn from the studies to date:

- majority of samples (> 98\%) were collected from live birds

- low prevalence of LPAIV infections was found in the framework of national 5-year surveillance with the overall prevalence of $0,61 \%$, and annual prevalence ranging from $0,36 \%$ (in 2012) to $0,98 \%$ (in 2009)

- increased incidence of AIV was found consistently in $3^{\text {rd }}$ and $4^{\text {th }}$ quarter of the years

- higher prevalence found in the surveillance within the scope of research projects was attributed to the fact that it had been conducted in a risk-based manner (e.g. not the whole area of the country but regions with previous history of AIV in wild birds, not allyear-round but enhanced sampling in specific periods of time, etc.)

- LPAIV of both H5 and H7 subtypes were detected, some of them sharing similarities with viruses detected in poultry in Europe

- no HPAIV were detected. 
The future challenges will focus on the continuation of active surveillance, enhanced sampling efforts at "high risk" areas, closer collaboration with ornithologists and further harmonization of sampling and transport procedures of specimens.

\subsubsection{Importance of the coastal area of Baltic Sea for bat migration}

Dr. Gunārs Pētersons Faculty of Veterinary Medicine, Latvia University of Agriculture, Latvia

Bats with more than 1100 species are important component of biodiversity but also significant reservoirs of zoonotic diseases. Beside their species diversity, long life span and large roosting aggregations ability to perform long-distance movements is a particular characteristic enhancing their effectiveness as hosts for viruses.

Seasonal movements are typical for all European bat species because of their different micro-climatic requirements for summer roosts and for hibernation sites. Some species of north-eastern European bat fauna find appropriate hibernation sites in the vicinity of their reproduction roosts but at least 6 species of bats perform long distance migrations to their hibernation areas situated in Central, Western and Southern Europe.

We have studied autumn migration of bats at the Pape Ornithological Research centre on the SW coast of Latvia since middle of $1980^{\text {th }}$. We captured them with large size funnel or Heligoland traps and monitored their nightly activity by ultrasound detectors.

We found that all species of local bat fauna occur on the coast during autumn migration in August-September, but long-distance migrants notably Nathusius' bats, pygmy bats, noctules and parti-coloured bats are strongly dominating. The accumulation of bats at the sea coast in autumn is highly weather-dependent. Slow or moderate eastern and southern winds facilitate a low altitude flight of bats. Under appropriate weather conditions at least 5000 bats cross observation site located on the coast.

Migrating bats may occupy buildings at the coastal area for few days using them as transient roosts. However there is yet no evidence that migrating bats should cause any threats to health of humans in Latvia. 


\subsubsection{Observations from FVO audits of monitoring and eradication programmes for diseases affecting wildlife}

Dr Lena Englund, European Commission, Food and Veterinary Office, Unit Animal Health and Animal Welfare, Grange, Dunsany, Co Meath, Ireland

All audits by the Food and Veterinary Office (FVO), in the EU Commission's DG Health and Consumers, are based on requirements in EU legislation. Specific measures for the prevention, monitoring or control of disease in wildlife are included in EU legislation for several diseases inter alia foot-and-mouth disease (FMD), African swine fever (ASF) and classical swine fever (CSF), and avian influenza (AI). Animal Health audits regularly check the implementation of EU-funded programmes, some of which may include monitoring and eradication of epizootic diseases in wildlife. Recent FVO audits have covered: FMD in wild boar and wild ruminants; CSF (including vaccination) in wild boar; ASF in wild boar; surveillance for AI; and vaccination against rabies in foxes.

With regard to active surveillance and vaccination of wild boar it is sometimes difficult to estimate reliably the pig population, which is a prerequisite for the determination of vaccine bait allocation and statistically sound sample numbers. Passive surveillance in wildlife is dependent on good cooperation with hunters and ornithologists. Several Member States have experienced that very few terrestrial wild animals are found dead and sampled for such programmes.

The EU is financing several vaccination programmes for wildlife, which comprise the spread of vaccine baits and monitoring of effect (sero-conversion) and sometimes vaccine uptake (marker substance in CSF vaccine). Vaccine bait distribution and sampling are often carried out by hunters. Such systems require training and official supervision to ensure that the right animals (age and geographical distribution) are vaccinated and sampled and that biosecurity measures are in place to prevent further spread of disease.

Vaccination programmes have sometimes resulted in below-target sero-conversion and may have been influenced by factors such as the estimates of the population, bait storage, bait distribution (spatial, temporal), non-target species taking baits, sample quality and the reliability of test results. 


\subsection{Sesion III: The mammal wildlife population: biodiversity and reservoir for infectious diseases}

\subsubsection{Report on the activities of the OIE Regional Representation in Moscow in 2013}

Professor Kazimieras Lukauskas, OIE

On the 6th of March 2013 the Agreement between the OIE and the Government of the Russian Federation regarding the establishment of the OIE Regional Representation in Moscow (RR in Moscow) was signed.

RR in Moscow carries out its activities in line with the OIE Fifth Strategic Plan for 2011-2015, recommendation of the OIE Regional Commission for Europe.

Activities of the OIE Regional Representation in Moscow include:

- Monitoring the epizootic situation.

- Exchange of the operational information and the latest techniques for the fight against epizootics.

- Collection, analysis and dissemination of scientific information of epizootics.

- Assistance in improving the legislation base in veterinary medicine.

The Representation participates in OIE Regional sub-regional and regional activities in Europe in collaboration with the Sub-regional Representation in Brussels. In 2013 (March-October) the RR in Moscow took part in over 30 conferences, workshops and meeting with CVOs.

Some of the events and actions:

- Participation in the PVS Evaluation mission to Turkmenistan; Meeting held by the OIE Regional Commission for Europe and CVOs of Denmark, Poland, Lithuania, Latvia, Serbia, Russia, Moldova, Croatia, and Czech Republic. Main topic: "Prevention of the spread of ASF" (Ukraine, Kiev); Organization of several meetings in Belarus, Ukraine and Poland to discuss the current African swine fever situation and the possibilities to strengthen and adapt preventive measures to the existing risk of the further spread of the disease and introduction of ASF into the EU.

- Taking part in the preparation of the Memorandum of understan ding between the Eurasian Economic Commission (EEC) and the OIE. This will contribute to the strengthening of Veterinary Services in Member States of the Customs Union and Single Economic Space (CU-SES) (Russia, Belarus and Kazakhstan) and strengthening of the 
epidemiological surveillance network in the Eastern Europe - Central Asia region.

The Regional Representation in Moscow has already scheduled some important tasks and activities for the coming year of 2014. Some of them: ASF and CSF prevention measures in Eastern Europe; FMD situation in Custom Union countries; Rabies and wild life rabies vaccination in Eastern Europe; Implementation of OIE Animal Welfare standards for Eastern Europe etc.

\subsubsection{Mammalian wildlife of importance for the control of infectious diseases in countries surrounding the Baltic Sea}

Aleksija Neimanis, Department of Pathology and Wildlife Diseases, National Veterinary Institute, Uppsala, Sweden

Understanding how a pathogen is maintained within an ecosystem is essential for effective prevention and control of infectious diseases that infect multiple hosts. Wildlife is often a source of pathogens for both humans and domestic species. Wildlife can act as true maintenance hosts (reservoirs), spill-over hosts or dead-end hosts. While the latter two situations may be less important for disease control, wild animals can still be useful sentinels for pathogen activity within an ecosystem.

A wide variety of mammal species inhabit countries around the Baltic Sea, but not all are equally important in the ecology of infectious diseases that impact humans and domestic animals. Much information comes from surveillance of hunted species because these are readily accessible and hunters are a risk group for any zoonotic diseases present. Wild canids, especially red fox (Vulpes vulpes) and raccoon dogs (Nyctereutes procyonoides), are important hosts for three of the most topical zoonoses: rabies, alveolar echinococcosis (Echinococcus multilocularis) and trichinosis (Trichinella sp.). In comparison, the wolf plays a less significant role. Raccoon dogs are an example of how an invasive species can change regional pathogen disease dynamics (e.g. rabies). Other large carnivores (lynx Lynx lynx, brown bear Ursus arctos) contribute to sylvatic cycles of Trichinella.

Wild ungulates, particularly the wild boar (Sus scrofa), are another potential source of important pathogens. These pathogens can be significant for domestic animal production (e.g. Classical and African swine fever) and humans (e.g. Trichinella) or both (e.g. Brucella suis). In some parts of Europe, wild boar and red deer (Cervus elaphus) are sources of bovine tuberculosis (Mycobacterium bovis). Small rodents, lagomorphs and bats carry a host of significant pathogens (e.g. hantaviruses, tularemia, European bat lyssavirus, respectively) addressed elsewhere. Alt- 
hough various infectious diseases have been documented in insectivores and mustelids, they are primarily spill-over infections.

\subsubsection{Epidemic surveillance and control of infectious animal diseases in the Leningrad and Kaliningrad oblasts of the Russian Federation}

Dr Artem Metlin, Prof. Konstantin Gruzdev, Dr Alexandr Shevtsov, Prof. Sergey Rybakov, Dr. Alisa Varentsova, Dr. Alexander Kononov. Federal Governmental Budgetary Institution "Federal Centre for Animal Health," Vladimir, Russia

Rabies is one of the most significant zoonoses in the world and its surveillance is of utmost importance. As major reservoirs of rabies are wild carnivores, rabies surveillance and control measures must be focused on the disease monitoring in wildlife. The Leningrad Oblast was free from rabies until 2009 when 5 raccoon dogs were found positive for rabies virus during the disease monitoring in wildlife at the border with the Novgorod Oblast. Despite vaccination campaigns using oral rabies vaccine are carried out in the Oblast annually. The Kaliningrad Oblast is endemic for rabies but due to EU-supported oral vaccination campaigns conducted since 2007, the number of rabies cases significantly decreased. Active monitoring of rabies was started in 2011 and currently the situation with rabies in wildlife is under the control of local veterinary laboratories and FGBI "ARRIAH".

An outbreak of classical swine fewer (CSF) was recorded in the Leningrad Oblast in 2012 but according to the official information no cases were recorded in 2013. No cases of CSF were reported in wild boars in the Leningrad Oblast either.

Primary introduction of African swine fever (ASF) to the territory of the Russian Federation occurred in 2007. Since then over 500 outbreaks of the disease were reported including cases in wild boars. In 2009 the first outbreak of ASF was registered in the Leningrad Oblast but no cases of ASF in wild boars were found in the Oblast at that time. The similar situation was observed in 2010 and 2011 when outbreaks were recorded only in domestic pigs. No outbreaks were reported in the Leningrad Oblast in 2012 and 2013.

The Kaliningrad Oblast is free from ASF and CSF. Monitoring of CSF and ASF is conducted according to the monitoring plans by local veterinary laboratories and FGBI "ARRIAH".

In 2013 in the framework of measures taken to maintain WTO agreement requirements FGBI "ARRIAH" researchers tested sera taken from deer and fallow deer in different regions of Russia. ELISA testing of 129 samples did not reveal antibodies to Schmallenberg Virus (SBV). 
SBV was not detected by PCR testing of 150 EDTA blood samples taken from mouflons in hunter's farms either.

\subsubsection{Experiences from surveillance and monitoring programs for diseases in marine mammals}

Aleksija Neimanis, Department of Pathology and Wildlife Diseases, National Veterinary Institute, Uppsala, Sweden

The Baltic Sea is inhabited by three species of seals (grey seals Halichoerus grypus, harbour seals Phoca vitulina and ringed seals Pusa hispida) of which the grey seal is the most widely distributed and abundant. The harbour porpoise (Phocoena phocoena) represents the main cetacean present, although other species infrequently are reported.

The largest threats to Baltic marine mammals are human activities and contaminants, with infectious disease playing a secondary role. One possible exception is phocine distemper virus (PDV) that has at least twice devastated nearby Kattegat and Skagerrak harbour seal populations and has the potential to infect terrestrial species. Seals, particularly grey seals, appear to be important in the ecology of an emerging Baltic parasite, the biliary fluke Pseudamphistomum truncatum. In addition to its pathogenic potential in grey seals, this parasite infects a variety of fish-eating mammals, including humans. Baltic grey seals also suffer from intestinal ulcers thought to be associated with Acanthocephalan parasitic infection. However, the severity of the lesions appears to be dependent upon host factors (immunity and healing responses) rather than on pathogenicity of the parasite. A limited number of grey seals are hunted each year and potential zoonoses for hunters include Mycoplas$m a$ (the suspected agent of 'seal finger'), seal pox and Trichinella. Marine mammals also are reservoirs for marine species of Brucella, which can infect terrestrial species, including humans. Presence of Brucella in Baltic populations requires further investigation.

Marine mammals generally act as sentinels of infectious diseases, being susceptible spill-over hosts for a variety of infections (e.g. Salmonella). Surveillance for infectious diseases in marine mammals is therefore important for understanding pathogen pollution of the marine environment. Because populations in the Baltic straddle international borders, collaborative international monitoring programs such as those within HELCOM are essential for recognizing significant diseases and other threats in these populations. 


\subsubsection{The wild boar and classical swine fever in Latvia}

Dr. Edvins Olševskis, Acting Director of the Veterinary Surveillance Department, Food and Veterinary Service of the Republic of Latvia

The wild boar population has increased constantly since previous classical swine fever (CSF) outbreak in Latvia (in 1996). The estimated size of wild boar population in Latvia has reached 70,000 individuals in 2013. The additional feeding of wild boar carried out by hunters is one of the main reasons for population growth.

The presence of CSF virus was confirmed in two wild boars in November 2012 in a framework of national CSF monitoring programme. The wild boar cases were followed by three outbreaks in backyard pig farms at the end of November. The results of epidemiological investigation showed the virus introduction from neighbouring eastern countries and link between wild boar and domestic pigs. Further 26 cases in wild boar were found by the end of 2012 within the infected area $\left(9,000 \mathrm{~km}^{2}\right)$ that was defined on a basis of the location of CSF positive cases. In 2013 (by 28 August), there are 33 virus positive cases found in wild boar. No CSF cases were found outside the infected area.

The oral vaccination programme was initiated in May 2013. The vaccination area was defined $\left(5,000 \mathrm{~km}^{2}\right)$ on a basis of the location of CSF cases and it covers a part of the infected area. Three double vaccination campaigns (spring, summer and autumn) were planned for 2013. There are 40,000 vaccine baits placed in wild boar feeding places during double vaccination campaign. After first two vaccination campaigns seroprevalence in wild boar population is $42 \%$. In addition, wild boar vaccination buffer zone 50-70 km in Belarus was established.

The implementation of CSF eradication measures is costly for country and emergency funds must be available. Vaccination includes costs of vaccine, distribution and post-vaccination monitoring. The implementation of the vaccination programme is facilitated by the EU as majority of programme components are co-financed. 


\subsubsection{The epidemiological situation of Rabies and implementation of disease eradication measures}

Dr Enel Niin, Veterinary and Food Board of Estonia, Animal Health, Welfare and Feed Department, Animal Health Bureau, Tallinn, Estonia

Rabies, an acute fatal infectious disease of animals and humans classically caused by Lyssavirus genotype 1, still causes worldwide more then 55,000 human deaths per year. Whereas by vaccination and population control, dog-mediated rabies has been eradicated in most European countries (excepted Turkey and Russia), since Second World War, a new epidemic of sylvatic rabies has been spreading in Europe via natural reservoir animals, raccoon dogs (Nyctereutes procyonoides) and red foxes (Vulpes vulpes). In large parts of Europe, disease become and remained endemic until late 1980s. Breakdown was achieved, when main principals of oral vaccination (ORV) of reservoir animals were elaborated in the middle of 1980s in Switzerland. Duet to large-scale and longterm oral vaccination programs based on aerial distribution of oral vaccine baits, the situation has improved remarkably. Majority of WesternEuropean countries (Switzerland, the Czech Republic, Germany, France, Finland etc.) have attained freedom from rabies-infection. Within last ten-year cause considerable decrease in rabies-cases has been reported in Eastern-Europe as well due to ORV programs launched with financial support of European Union. Success in rabies control relies on several important aspects including conducting risk-based intensive surveillance, preparing appropriate rabies control strategy, enforcing ORV of wildlife, informing the public, securing sufficient financial and nonfinancial resources, evaluation of ORV activities etc. As migration of wildlife is not respecting country borders to eradicate the disease in a country surrounded by infected areas and maintain rabies-freedom, good co-operation with neighboring countries could be crucial.

Epidemiology of sylvatic rabies, details of the rabies control strategy and data demonstrating efficacy of oral vaccination campaigns will be addressed and discussed based on the experience of Estonian Republic, a country declaring itself free from rabies in spring of running year. 


\subsubsection{Rodent-Borne Pathogens Around The Baltic}

Heikki Henttonen, Finnish Forest Research Institute

RoBos (rodent-borne viral pathogens) in common practice include hantaviruses, arenaviruses, cowpox virus, and some others like Ljungan virus and Borna virus are occasionally considered. Hantaviruses in Eurasia cause hemorrhagic fever with renal syndrome (HFRS). Puumala virus, carried by the bank vole Myodes glareolus, is by far the most widespread and common hantavirus in Europe, and causes annually thousands of human cases. Human epidemics follow bank vole population fluctuations. Special emphasis is paid to epidemiology of this virus and the disease nephropathia epidemica, often considered a mild form of HFRS. Another pathogenic hantavirus in Europe is the Dobrava/Belgrade virus, that is divided into several genotypes. Around the Baltic, genotypes Kurkino and Saaremaa occur in the striped field mouse Apodemus agrarius. Tula hantavirus, carried by Microtus voles and occasionally by water voles Arvicola, can infect humans, but is usually considered nonpathogenic. Seoul hantavirus carried by rats occurs in Europe, and has recently been found in pet rats e.g. in Sweden, and is a human pathogen.

The only arenavirus earlier thought to occur n Eurasia was lymphocytic choriomeningitis virus, LCMV that was mainly connected to house mouse Mus, sometimes to pet hamsters and like. However, new studies indicate LCMV antibodies practically in all wild rodent species in Europe, and sequencing has recovered independent lineages in different host species. LCMV may in fact be a complex of related viruses.

Cross-protection by smallpox vaccine against cowpox virus prevented human cases, but after the cessation of vaccination program, human cowpox cases have started to appear. Cowpox is common in rodents.

Tularemia can well be considered a robo-pathogen because voles and lemmíngs are reservoirs. Even though human tularemia at northern latitudes is typically a mosquito-borne disease, the human incidence follows vole cycle with one year lag, indicating that both voles and mosquitoes are included in the epidemiology.

Echinococcus multilocularis is spreading. The parasite is found from the Baltic States, Poland. Germany, parts of Denmark, recently in Sweden, but no so far from Finland and mainland Norway. The situation in Russia between Estonia and Finland is unknown (at least for Finns). 


\subsection{Session IV: Wildlife diseases and contingency planning}

\subsubsection{How will the climatic change affect the ecosystems of the Baltic Sea coastal areas?}

Dr. Judita Liukaitytè, Vilnius University, Lithuania

Climate change has general impact on our life, our environment and ecosystems. The Intergovernmental Panel on Climate Change (IPCC) reports have documented that anthropogenic climate change is an ongoing trend, which may be associated with grave implications if will continue into the future.

Climate warming is more pronounced at northern latitudes. As temperatures are considered to be a major factor determining the environment, they obviously influence success and survival of reproduction, and the spread of the fauna and flora. Changing temperatures may affect the adaptation ability in animals, which will provoke their extinction.

The warming trend for the entire globe was about $0.05{ }^{\circ} \mathrm{C} /$ decade from 1861-2000, while the trend for the Baltic Sea basin has been somewhat larger, $0.08{ }^{\circ} \mathrm{C} /$ decade. The reflection of this warming trend may be seen in a decrease in the number of very cold days during winter as well as a decrease in the duration of the ice cover and its thickness in many rivers and lakes, particularly in the eastern and south-eastern Baltic Sea basin.

Consequently, by the late 21st century, forests are likely to have contracted in the south and expanded in the north, and distributions of European plant species are projected to have shifted several hundred kilometres to the north.

The response to observed climate change is quite noticeable in the distribution of animal species, as well. Europe's insects, birds, and mammals are moving northwards, and migration degree in bird species increases from the south northwards and decreases, on the contrary, from the north southwards. Scientists agree that climatic conditions are one of the main definitions of the limits of species ranges. The annual cycle and fluctuation limits of day duration, temperature and humidity ranges are major factors limiting species distribution. 


\subsubsection{Contingency planning: How to respond to the wildlife/production animals' interface?}

Mariann Chriél, Senior Adviser, DVM, PhD Section for Public sector service and commercial diagnostics, National Veterinary Institute, Technical University of Denmark, Denmark

Wildlife populations are often able to move freely between geographic locations - ignoring borders and farm restrictions. This means that you may monitor diseases in wildlife from a different area than anticipated. Sharing wildlife populations in border regions of countries with different zoo-sanitary status may lead to different regulation of the wildlife. Migrating birds are good examples of this sharing of populations, too.

Therefore the population structure, density, distribution and origin of individuals may often not be known in details. The presence of susceptible species or reservoir hosts is of outmost importance for the success of control programs in commercial animal productions. Estimation of prevalence in wildlife populations pose the risk to be overestimated if the disease of concern have detrimental effect on the health and/or debilitated individuals have a greater propensity to be collected and examined.

Before implementing surveillance or monitoring of disease(s) in wildlife the objective must be defined; is this for game management; to determine the role of reservoir hosts for zoonotic diseases or regulated diseases in livestock. Monitoring of diseases in wild birds and mammals may be initiated in order to assess the general health status of a given wildlife population, including any population related effects of disease occurrence and effects of human activity in a given area. However, more often the purpose is to demonstrate that a specific disease is not present in a country or to determine the prevalence and geographical distribution of the pathogen in a specific population. Wildlife populations may also serve as sentinels for "early warning" in the context of emerging diseases like Blue tongue virus or Schmallenberg virus. Identification of the presence of anthropogenic substances and spatial distribution in the environment may only be possible in wild animals (e.g. DDT and PCB). 



\section{Observations, Conclusions and Recommendations}

The Nordic -Baltic seminar on the role of wildlife as reservoir and/or spread of infectious animal diseases in the coastal areas of countries bordering the Baltic Sea was held in Gdansk, Poland from 2-3 October 2013.

The objectives of the seminar included

- To review the wildlife populations as reservoirs for infectious diseases such as avian influenza, diseases of wild boar, rabies and vector borne diseases.

- To outline the potential risk of spreading infectious animal diseases by wildlife inhabiting the coastal areas of the Baltic Sea.

- To review risk based surveillance of infectious diseases occurring or potentially occurring in terrestrial animals in the coastal area in the light of climatic changes.

- To explore the possibility in making disease surveillance more efficient and obtain savings in relation to laboratory examinations.

Furthermore, the seminar had focus on how to respond to the wildlife/production animals' interface.

Day one of the seminar highlighted how the wildlife have high economic, ecological, social and cultural value for the coastal areas bordering the Baltic Sea and have it contributes to recreation and tourism. Furthermore information was provided on activities of OIEs working group on wildlife diseases, the Baltic Sea avian wildlife population, infectious viral diseases in bird populations, disease surveillance programmes, bat migration and observations from EU audits covering monitoring and surveillance of wildlife diseases.

The second day had focus on the mammal wildife population with regard to biodiversity and reservoir for infectious diseases, disease surveillance and monitoring programmes, the wildlife/human interface concerning certain infectious diseases and contingency planning with regard to the response of veterinary services to the wildlife/production animals' interface.

The seminar had a total of 92 participants coming from the nine countries - Denmark, Sweden, Finland, Russia, Estonia, Latvia, Lithuania, Poland and Germany - bordering the Baltic Sea, Iceland and Norway.

The seminar showed the importance of having: 
- constructive dialogues and close cooperation between wildlife scientists, veterinary administrations at central and local level, livestock owners, the public and managers involved in the protection of wildlife and in the protection of animal and human health

- good cross border cooperation between neighbouring countries.

The presentations made during the seminar by speakers coming from the countries bordering the Baltic Sea, the OIE and the EU provided an excellent basis for a valuable exchange of views between the experts and the participants of the seminar. The outcome of the discussions is reflected in the recommendations listed below.

\subsection{Recommendations}

- Disease surveillance is the continuous monitoring of the occurrence of disease within a population through the collection, collation, analysis and dissemination of disease -related data. Man made borders are not respected by wildlife populations and challenges are often faced during the conduct of surveillance for wildlife diseases in border areas.

It is recommended that the Nordic Council of Ministers is informed about border area surveillance challenges and be encouraged to review the strategy adopted in 2006 with the aim to support activities which can promote the measures available for solving animal health problems in border areas.

- Contingency planning addressing the prevention and control of diseases in wildlife calls for a close cooperation between veterinarians, wildlife biologists, epidemiologists, hunters and others engaged in the management of wildlife populations and cross border cooperation.

It is recommended that the Nordic-Baltic Veterinary Contingency Group takes the initiative to prepare and conduct a simulation exercise addressing a disease in wildlife. One of the objectives should be the cooperation of all relevant groups of professionals across borders.

- The role of aquatic wild bird populations as reservoirs of influenza A viruses has been well described; this include the circulation of Low Pathogenic avian influenza virus, which have caused the majority of recent outbreaks of notifiable LPAI in poultry in the EU and recently caused clinical disease in humans. 
It is recommended by the participants of the seminar that the EU and the Countries bordering the Baltic Sea provide funding for targeted active surveillance of avian influenza in wild birds

- The results obtained from sampling and testing of specimens originating from surveillance for disease in wildlife may be difficult to interpret

It is recommended that the Nordic-Baltic Veterinary Contingency Group explore the possibility on how expertise needed for the planning, implementation and epidemiological evaluation of wildlife disease surveillance programmes can be provided

\subsection{Acknowledgements}

The organizers of the Nordic-Baltic seminar on Contingency planning for the next decade would like to express their thanks to the Nordic Council of Ministers for the political support and the financial support made available for the preparation, implementation and valuation of the seminar.

The support made it possible for the national experts from the Nordic and Baltic countries to meet with representatives of international organisations and discuss topics of mutual interest within the context of contingency planning.

A special thank shall be addressed to all the speakers for the well prepared presentations, the chairmen managing competently the different sessions and to all the participants for active contributions to the success of the seminar. It is our hope that many valuable networks has been established for the future work concerning animal disease preparedness and contingency planning.

The seminar would not have conducted with success without the valuable support given by Dr. Janusz Zwiazek the Chief Veterinary Officer of Poland and the staff of the Polish National Veterinary Administration. 



\section{Annexes}

\subsection{Annex 1 Programme}

Seminar on the role of the wildlife as reservoir and /or spread of infectious animal diseases in the coastal areas of countries bordering the Baltic Sea

Time: 2-3 October 2013

Place: Best Western Plus Arkon Park Hotel, Gdansk, Poland

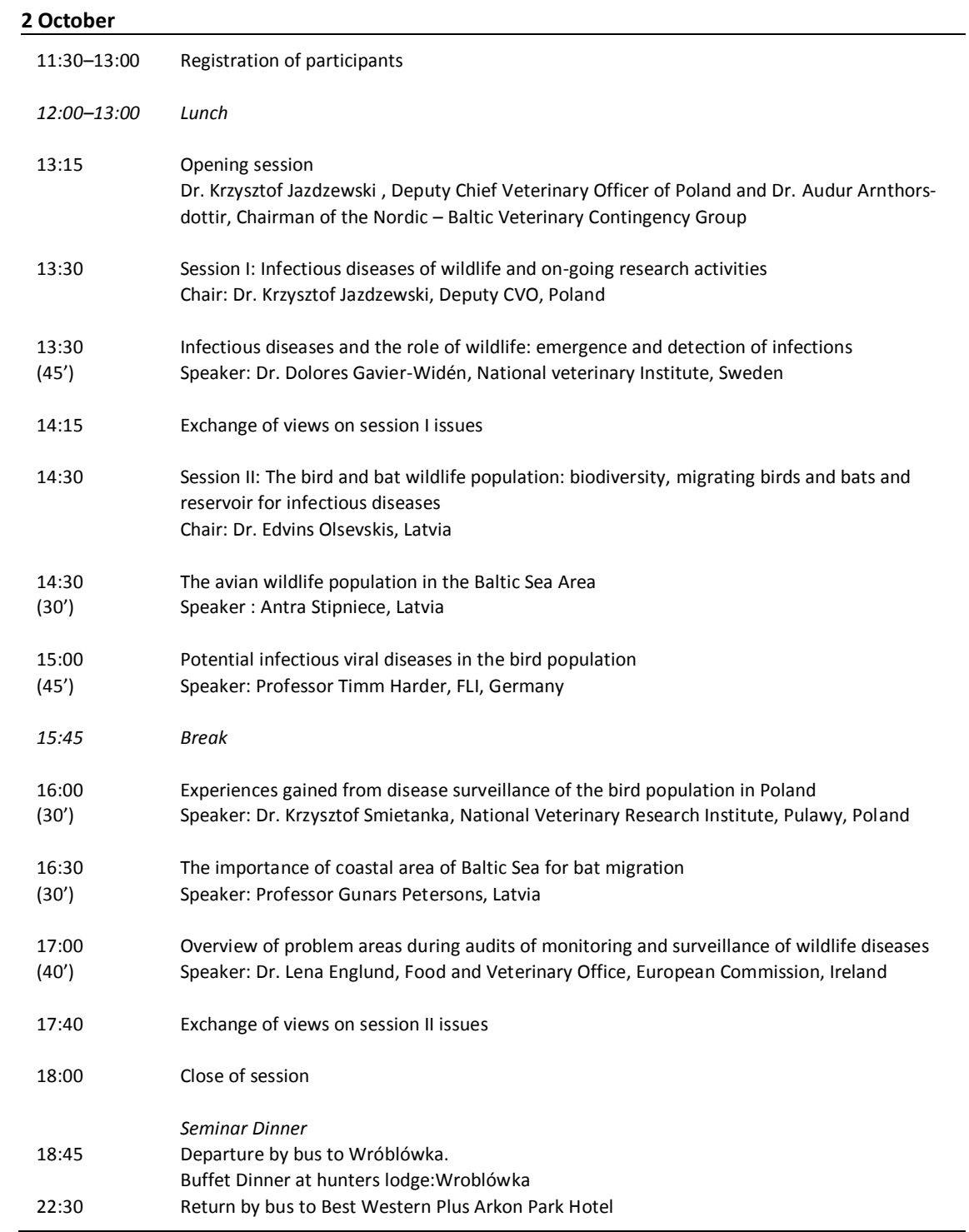




\begin{tabular}{|c|c|}
\hline 09:00 & $\begin{array}{l}\text { Session III: The mammal wildlife population: biodiversity and reservoir for infectious diseases } \\
\text { Chair: Dr. Sirpa Kiviruusu, Finland }\end{array}$ \\
\hline 09:00 & $\begin{array}{l}\text { Report on the activities of the OIE Regional Representation in Moscow in } 2013 \\
\text { Speaker: Professor Kazimieras Lukauskas, OIE }\end{array}$ \\
\hline $\begin{array}{l}09: 15 \\
\left(30^{\prime}\right)\end{array}$ & $\begin{array}{l}\text { The mammal wildlife population in countries with coastal areas to the Baltic Sea of importance } \\
\text { for the control of infectious diseases } \\
\text { Speaker: Aleksija Neimanis, National veterinary Institute, Sweden }\end{array}$ \\
\hline 09:45 & $\begin{array}{l}\text { Epidemic surveillance and control of infectious animal diseases in the Leningrad and Kaliningrad } \\
\text { Oblasts of the Russian Federation }\end{array}$ \\
\hline$\left(45^{\prime}\right)$ & $\begin{array}{l}\text { Speaker: Dr. Artem Metlin, Laboratory for diagnosis of farm animal diseases and fish, Vladimir, } \\
\text { The Russian Fecderation }\end{array}$ \\
\hline $\begin{array}{l}10: 30 \\
\left(30^{\prime}\right)\end{array}$ & $\begin{array}{l}\text { Experiences from surveillance and monitoring programmes for diseases in marine mammals } \\
\text { Speaker: Aleksija Neimanis, National veterinary Institute, Sweden }\end{array}$ \\
\hline 11:00 & Exchange of views session III issues \\
\hline 11:15 & Break \\
\hline $\begin{array}{l}11: 30 \\
\left(30^{\prime}\right)\end{array}$ & $\begin{array}{l}\text { The wild boar and classical swine fever in Latvia } \\
\text { Speaker: Dr. Edvins Olsevskis, Latvia }\end{array}$ \\
\hline $\begin{array}{l}12: 00 \\
\left(30^{\prime}\right)\end{array}$ & $\begin{array}{l}\text { The epidemiological situation of Rabies and implementation of disease eradication measures } \\
\text { Speaker: Dr. Enel Niin, Veterinary and Food Board, Estonia }\end{array}$ \\
\hline $\begin{array}{l}12: 30 \\
\left(40^{\prime}\right)\end{array}$ & $\begin{array}{l}\text { The wildlife/human interface with special reference to small mammals } \\
\text { Speaker: Professor Heikki Henttonen, Finland }\end{array}$ \\
\hline $13: 10$ & Exchange of views session III issues \\
\hline 13:15 & Buffet Lunch \\
\hline 14:00 & $\begin{array}{l}\text { Session IV: Wildlife diseases and contingency planning } \\
\text { Chair: Dr. Audur Arnthorsdottir, Iceland }\end{array}$ \\
\hline $\begin{array}{r}14: 00 \\
\left(20^{\prime}\right)\end{array}$ & $\begin{array}{l}\text { How will the climatic change affect the ecosystems of the Baltic Sea coastal areas? } \\
\text { Speaker: Dr. Judita Liukaité, Vilnius University, Lithuania }\end{array}$ \\
\hline $\begin{array}{l}14: 20 \\
\left(30^{\prime}\right)\end{array}$ & $\begin{array}{l}\text { Contingency planning: How to respond to the wildlife/production animals' interface? } \\
\text { Speaker: Dr. Mariann Chriél, National Veterinary Institute, Denmark }\end{array}$ \\
\hline $14: 50$ & Discussion, conclusions and recommendations \\
\hline $15: 30$ & Close of seminar \\
\hline
\end{tabular}

\subsection{Annex 2. The Organizing Committee}

The Nordic-Baltic Veterinary Contingency Group established in 2012 an Organizing Committee for the preparation and implementation of the seminar on Seminar on the role of the wildlife as reservoir and /or spread of infectious animal diseases in the coastal areas of countries bordering the Baltic Sea.

The Members of the Organizing Committee were: 


\begin{tabular}{lll}
\hline Camilla Brasch Andersen & the Danish Veterinary and Food Administration & Denmark \\
Hanne M. Hansen & the Danish Veterinary and Food Administration & Denmark \\
Maarja Kristian & the Veterinary and Food Board & Estonia \\
Pawel Niemczuk & the General Veterinary Inspectorate & Poland \\
Krzysztof Jazdzewski & the General Veterinary Inspectorate & Poland \\
Audur Arnthorsdottir & the Food and >veterinary Authority & Iceland \\
Jørgen M. Westergaard & ADC-Consult & Denmark \\
\hline
\end{tabular}

The work of the Committee was in the Technical Secretariat assisted by Anne Jyderup, the Danish Veterinary and Food Administration.

\subsection{Annex 3. Evaluation}

An evaluation form was as a part of the hand outs given to all participants at the time of registration. The form consisted of 3 sections:

- General questions

- Evaluation of main sessions

- Complementary comments

The evaluation scale to be used during the evaluation was: $1=$ poor and $5=$ excellent.

The completed forms, total of 32 , were collected at the end of the seminar and information - feedback - obtained from the forms is highlighted below.

\begin{tabular}{|c|c|c|c|c|c|c|}
\hline General questions & 1 & 2 & 3 & 4 & 5 & $\begin{array}{r}\text { Not } \\
\text { relevant }\end{array}$ \\
\hline $\begin{array}{l}\text { Did the seminar meet your expectations in relation to } \\
\text { networking and sharing experiences }\end{array}$ & & & 2 & 11 & 19 & \\
\hline $\begin{array}{l}\text { Did you feel you had the necessary prerequisites } \\
\text { (knowledge skills etc) to be able to benefit from the seminar }\end{array}$ & & & & 9 & 24 & \\
\hline The choice of topics for the different sessions were relevant & & & & 12 & 20 & \\
\hline How did you find the supplied material, hand outs, etc. & 1 & 5 & 10 & 9 & 4 & 1 \\
\hline $\begin{array}{l}\text { The seminar has improved my knowledge about the wildlife } \\
\text { diseases and contingency planning }\end{array}$ & & & 1 & 15 & 14 & \\
\hline Over all, how did you find the seminar & & & & 14 & 17 & \\
\hline & 1 & 5 & 13 & 70 & 98 & 1 \\
\hline
\end{tabular}

It is clear from the answers received to the general questions that the participants by and large used 4 or 5 on the evaluation scale with the exception to the question about the supplied material and hand outs. 
In the seminar management plan and in the Guidelines prepared for abstracts and presentations it was scheduled that Abstracts should arrive not later than $15^{\text {th }}$ August, and PowerPoint presentations not later than $15^{\text {th }}$ September.

Upon the receipt of the material it should be placed on the website before the start of the seminar. Unfortunately, circumstances made it impossible to adhere to the provisions of the seminar management plan. However, it was possible shortly after the seminar for the participants to consult the website: http://www.norden.org/balticsea_with regard to abstracts, presentations, participants, conclusions and recommendations.

\begin{tabular}{|c|c|c|c|c|c|c|}
\hline Evaluation of main sessions & 1 & 2 & 3 & 4 & 5 & $\begin{array}{r}\text { Not } \\
\text { relevant }\end{array}$ \\
\hline $\begin{array}{l}\text { Session I: Infectious diseases of wildlife and on-going Research } \\
\text { activities }\end{array}$ & & & 3 & 11 & 17 & \\
\hline $\begin{array}{l}\text { Session II: The bird and bat wildlife population: biodiversi- } \\
\text { ty,Migrating birds and bats and reservoir }\end{array}$ & & & 1 & 11 & 19 & \\
\hline $\begin{array}{l}\text { Session III: The mammal wildlife population: biodiversity and } \\
\text { reservoir for infectious diseases }\end{array}$ & & & 2 & 12 & 16 & 1 \\
\hline \multirow[t]{2}{*}{ Session IV: Wildlife diseases and contingency planning } & & 1 & 3 & 8 & 13 & 1 \\
\hline & & 1 & 9 & 42 & 55 & 1 \\
\hline
\end{tabular}

All 4 sessions appears to have been well received. The scores, using 4 and 5 on the evaluation scale together, for the different sessions were for Session I $(90,3 \%)$, Session II $(96,7 \%)$, Session III $(90,3 \%)$ and session IV $(80,7 \%)$.

With regard to complementary comments to the evaluation form the participants were invited to respond to the aspects or issues listed under the following 5 heading:

1. Comments ( in particular on points, where your answer was negative)

2. Which PowerPoint presentation was of most interest to you

3. What was the best part of the seminar?

4. What could be improved?

5. Topics suggested for future seminar or workshop.

The handwritten comments ( a total of 65 ) made by the participants with regard to the presentations and discussions during the 4 different sessions (I-IV) and to the management of the seminar were found very valuable and the comments re-in forced the views expressed in the two tables shown above.

With regard to topics for future seminars or workshops a number of topics were mentioned and included: 
- Disease surveillance

- Surveillance systems/programs: theory, set-up, implementation etc.

- Epidemic surveillance and control of infectious diseases

- How to build up and manage a quarantine station?

- How to analyse routine laboratory data. What is possible to learn from those data and what could be false

- How to assess (monitor) wildlife populations (cost effective way)

- Infectious equine diseases

- Seminar with closer tie-in between climatic change, emerging diseases and contingency planning

- One health issues

- Control of ASF in Europe

- Bluetongue, FMD, ASF, and CSF in Eastern Europe

\subsubsection{Organization chart}

The activities of the Nordic-Baltic Veterinary Contingency Group are carried out within the framework of allocations given to Nordic working group for microbiology and animal health/animal welfare.

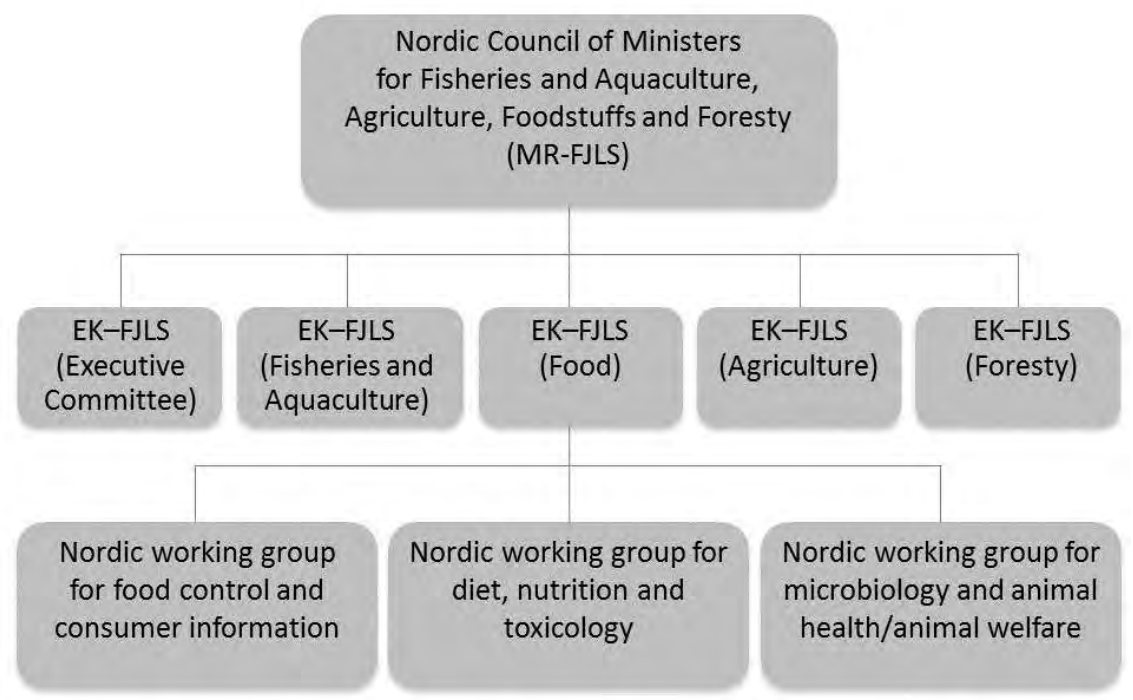




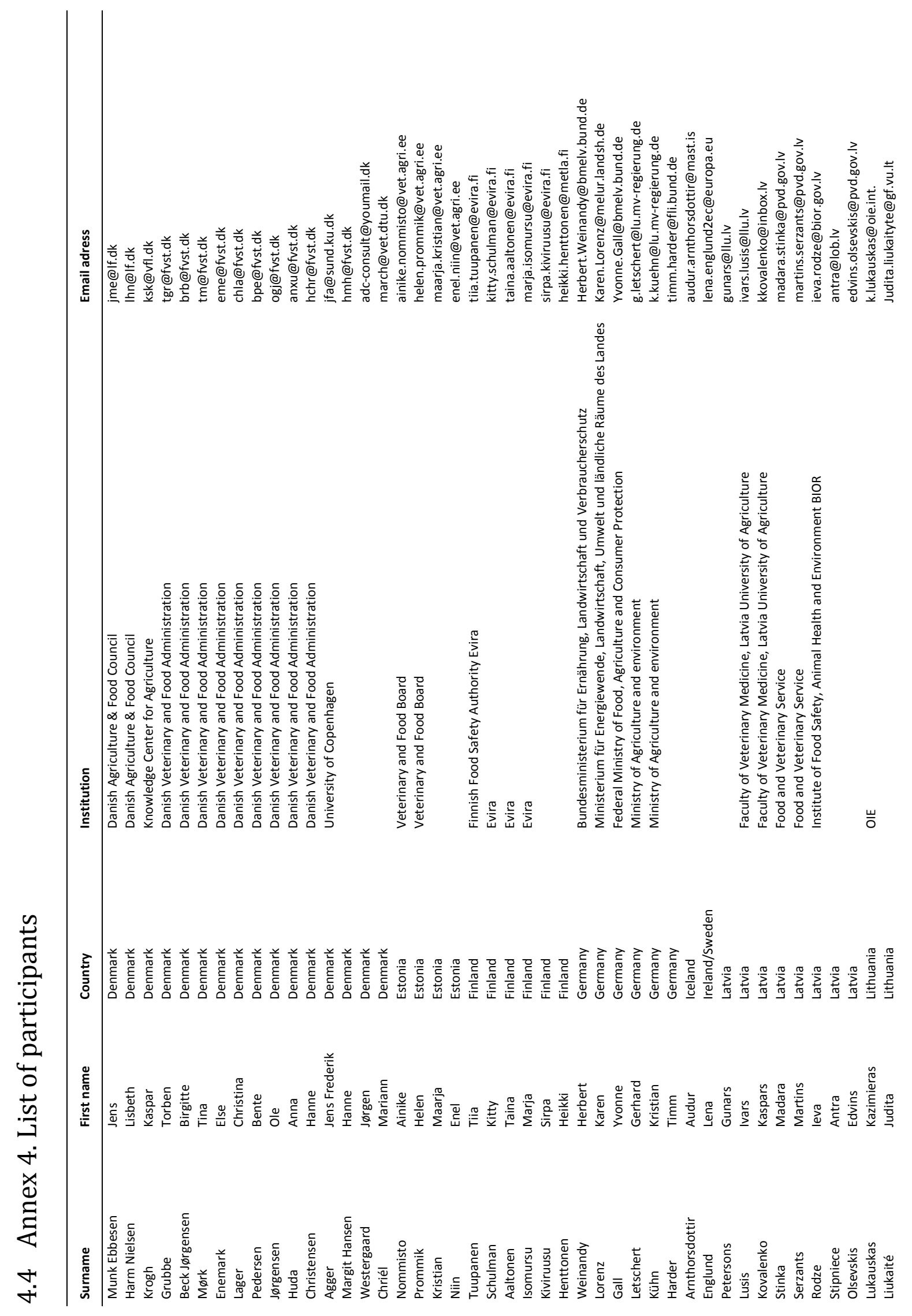




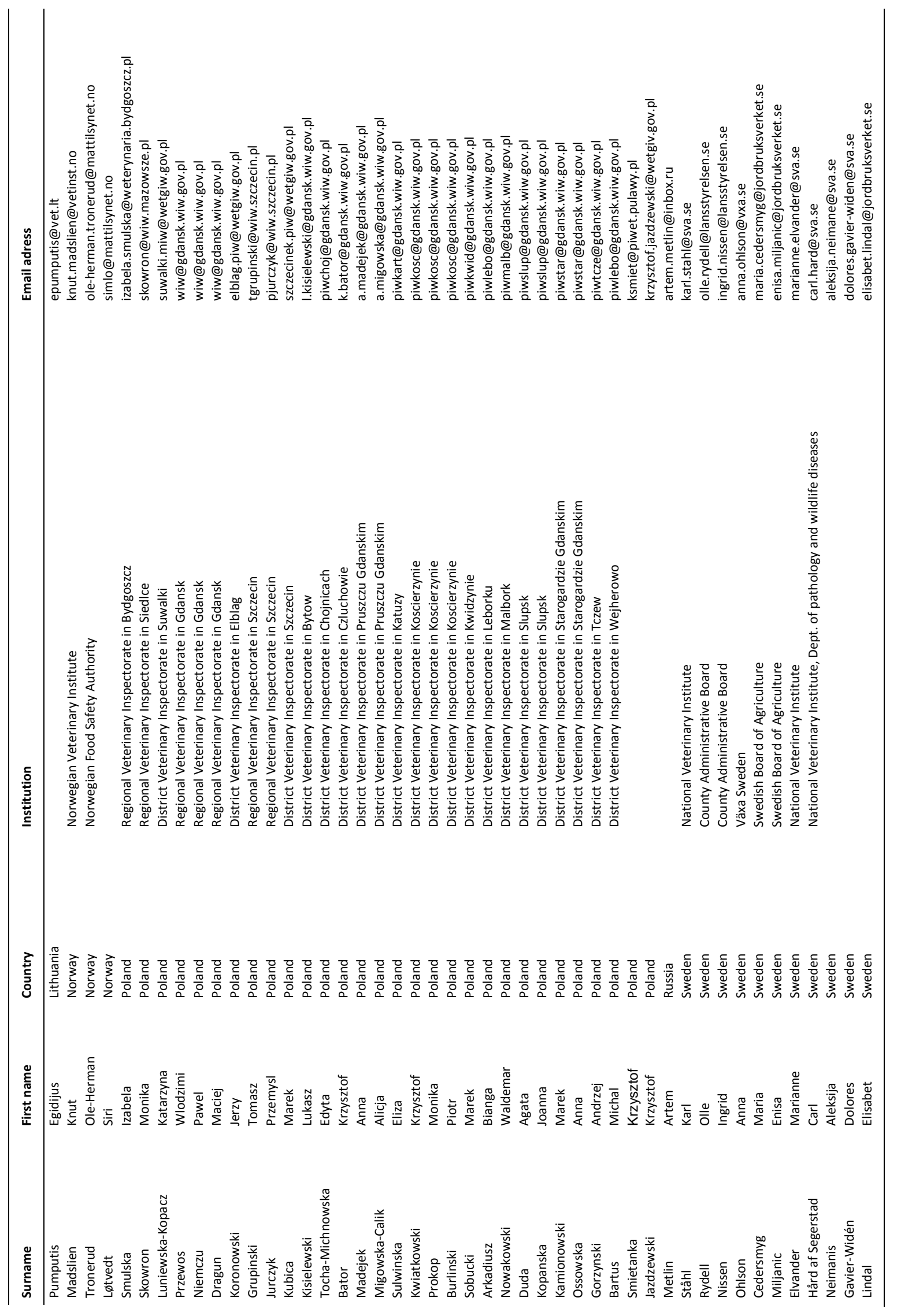


Nordic Council of Ministers

Ved Stranden 18

DK-1061 Copenhagen $\mathrm{K}$

www.norden.org

\section{Wildlife and Infectious Animal Diseases}

Many infectious diseases of domestic animals and humans have reservoirs in wild animals. One of these diseases is rabies which worldwide causes more than 55.000 deaths pr. year. Climatic changes, human population growth, certain livestock production systems and continued globalization enhance the interface between wildlife, domestic animals and man. The wildlife component of this triad has received inadequate attention in the past to effectively protect man, livestock, poultry and pet animals. The seminar held in Gdansk, Poland 2 - 3 October 2013 highlighted how the wildlife has high economic, ecological, social and cultural value for the coastal areas bordering the Baltic Sea and how it contributes to recreation. Nevertheless, the wildlife plays also an important role in the spread of infectious diseases and thereby the need for focus on disease surveillance and control measures. 